\title{
TOWARDS FOOD SECURITY OF ALTERNATIVE DIETARY PROTEINS: A COMPARISON BETWEEN SPAIN AND THE DOMINICAN REPUBLIC
}

\author{
Cristino A. Gómez-Luciano ${ }^{1}$, Frank Vriesekoop ${ }^{2}$ and Beatriz Urbano ${ }^{3 *}$ \\ ${ }^{1)}$ Instituto Especializado de Estudios Superiores Loyola, San Cristobal, \\ Dominican Republic \\ ${ }^{2)}$ Department of Food Science, Harper Adams University College, Newport, \\ United Kingdom \\ ${ }^{3)}$ Department of Agricultural and Forestry Engineering, University of Valladolid, \\ Palencia, Spain
}

Please cite this article as:

Gómez-Luciano, A.C., Vriesekoop, F. and Urbano, B., 2019. Towards Food Security of Alternative Dietary Proteins: a Comparison between Spain and the Dominican Republic. Amfiteatru Economic, 21(51), pp. 393-407.

DOI: $10.24818 / \mathrm{EA} / 2019 / 51 / 393$
Article History

Received: 23 December 2018

Revised: 17 February 2019

Accepted: 6 March 2019

\begin{abstract}
Current environmental and health concerns encourage a shift towards more sustainable diets. A variety of options are currently being investigated to achieve the food security of alternative-to-meat dietary proteins. The food security of alternative to meat proteins will require attention to the availability, the access, the supply stability and the food safety and quality. The aim of this research is to get insight on consumers' food attitudes in order to achieve food security of four alternatives to meat proteins, namely, plant-based proteins, mycoproteins, cultured meat proteins and insect proteins in different development contexts in Spain and the Dominican Republic. In doing so, the research analyses meat consumption, reduces consumers' attitudes using a principal component analysis, predicts first adopters of alternative dietary proteins using a Chi-square test and ranks preferred alternative dietary proteins using a multicriteria decision-making method. The results show that plant-based proteins are the best positioned alternative, while insects are the worst positioned in the Dominican Republic. Gender and education in the Dominican Republic and gender, education and age in Spain are significant factors for the adoption of alternative to meat proteins. Health and convenience attitudes may determine the adoption of alternative dietary proteins in Spain and the Dominican Republic. This research contributes to identifying the consumers' attitudes to encourage the dietary shift to alternative to meat proteins. It can help industry to market alternative-to-meat proteins in different development contexts to achieve food security.
\end{abstract}

Keywords: consumers' attitudes; alternative-to-meat proteins; preferences; multicriteria decision making (MCDM); principal component analysis (PCA); Spain; Dominican Republic.

JEL Classification: O13, Q18.

\footnotetext{
* Corresponding author, Beatriz Urbano - beaturb@iaf.uva.es
} 